Khazanah: Jurnal Studi Islam dan Humaniora

ISSN: 0215-837X (p); 2460-7606 (e), Vol. 17 (2), 2019, pp. 263-282

DOI: $10.18592 /$ khazanah.v17i2.3207

Submit : 14/08/2019 Review : 30/08/2019 Publish : 31/12/2019

\title{
JEJAK-JEJAK PLURALISME AGAMA DALAM SUFISME
}

\author{
Ilham Masykuri Hamdi \\ UIN Antasari Banjarmasin \\ mh@gmail.com
}

\begin{abstract}
This article intends to explore Sufism about the pluralism of religion. Khazanah Sufism is known synonymous with the esoteric approach in religion. Through this esoteric approach, the unity of religions or pluralism is very likely to be achieved, because all religions ultimately meet God. In Islam this aspect of esotericism is known to be discussed by Sufism or Sufi figures who have many concepts of unity (al-wahdat) such as Wahdat al-Wujud, Wabdat al-Syubud, Wahdat al-Ummah and Wahdat al-Adyan. This article is the result of library research that raises the issue of Sufi treasures around religious pluralism. The study in this paper can be considered important, theoretically besides being able to enrich the treasury of Islamic thought more specifically in the field of Sufism, it can also strengthen the theological basis for understanding pluralism of religion, which at the level of praxis can encourage a more harmonious relationship between and among adherents of religion that different. Moreover, if so far the discourse on religious pluralism is considered to always refer to the works of Western religious scholars, those who define pluralism as the view that the One manifests to many or that particular religions are a response to the Almighty, in fact some Sufism or Sufi figures actually have long, first discuss it philosophically and deeply.
\end{abstract}

Keywords: Religious Pluralism; Esotericism; Sufism; Wabdatul Adyan

\begin{abstract}
Abstrak: Artikel ini bermaksud mengeksplorasi khazanah tasawnf seputar pluralism agama. Khazanah tasawuf dikenal identik dengan pendekatan esoterisme dalam beragama. Melalui pendekatan esoterisme ini, kesatuan agama-agama atau pluralisme sangat mungkin tercapai, karena semua agama-agama pada akbirnya bertemu pada Tuhan. Di dalam Islam aspek esoterisme ini dikenal diperbincangan para tokoh tasawnf atau sufi yang banyake memiliki konsep tentang paham kesatuan (al-wahdat) seperti Wabdat alWujud, Wabdat al-Syubud, Wabdat al-Ummah dan Wabdat al-Adyan. Artikel ini merupakan hasil dari penelitian kepustakaan (library research) yang mengangkat persoalan khazanah sufi seputar pluralisme agama. Studi dalam tulisan ini dapat dianggap penting, secara teoritis disamping dapat memperkaya khazanah pemikiran Islam secara lebih spesifik di bidang tasawnf, juga dapat mengukubkan basis teologis bagi pabam kemajemukan agama, yang pada tingkat praksis dapat mendorong terjadinya bubungan yang lebih harmonis intra dan antar pemeluk agama yang berbeda-beda. Lebih dari itu, kalau selama ini diskursus tentang pluralism agama dianggap selalu merujuk kepada karya-karya sarjana agama Barat, mereka yang mendefinisikan pluralisme sebagai pandangan bahwa Yang Maha Esa memanifestasi pada yang banyak atau bahwa agama-agama partikular merupakan respons terhadap Yang Mahaesa, ternyata beberapa tokoh tasawuf atau sufi sesunggubnya telah lama, lebib dabulu mendiskusikan hal itu secara filosofis dan mendalam.
\end{abstract}

Kata kunci: Pluralisme Agama; Esoterisme; Sufisme; Wabdatul Adyan

\section{Pendahuluan}

Tantangan paling besar dalam kehidupan beragama sekarang ini adalah bagaimana seorang beragama bisa mendefinisikan dirinya di tengah agama-agama lain. Atau dalam istilah yang lebih teknis, bagaimana bisa berteologi dalam konteks agama- 
agama. Pada tingkat ini sering muncul kebingungan-kebingungan, khususnya menyangkut bagaimana kita harus mendefinisikan diri di tengah agama-agama lain. Banyak juga pertanyaan yang terkait mengemuka, apakah dengan banyak agama berarti banyak Tuhan, ataukah Tuhan itu satu namun didekati oleh berbagai ragam pemeluk agama? Jika agama ternyata beragam, apakah keragaman itu semata produk sejarah, ataukah ada campur tangan Tuhan yang telah mengirimkan beragam rasul-Nya dengan ajaran yang berbesa-beda?

Untuk itu paling tidak, dewasa ini para ahli memetakan ada tiga sikap dalam dialog agama atau teologi agama-agama. Pertama, sikap yang "eksklusif' dalam melihat agama lain. Agama-agama lain adalah jalan yang salah, yang menyesatkan bagi para pengikutnya. Kedua, sikap "inklusif' yang melihat agama-agama lain adalah bentuk implisit agama kita. Dan ketiga, sikap pluralis yang bisa terekspresi dalam macammacam rumusan, misalnya: "agama-agama lain adalah jalan yang sama-sama sah untuk mencapai Kebenaran yang sama”, "agama-agama lain berbicara secara berbeda, tetapi merupakan Kebenaran-kebenaran yang sama sah", atau "setiap agama mengekspresikan bagian penting sebuah Kebenaran". ${ }^{1}$

Tentang pluralisme agamapun tak luput dari perdebatan. Apakah pluralisme agama berarti menyamakan semua agama, ataukah sekadar sikap mengakui eksistensi agama-agama dengan keunikannya masing masing. Walaupun topik pluralisme agama ini dalam masyarakat menimbulkan kontroversi, tetapi tentunya dalam dunia akademis, apa yang oleh masyarakat disebut kontroversial sesungguhnya merupakan hal yang biasa biasa saja. Ilmu pengetahuan berkembang justru ketika dihadapkan pada berbagai persoalan kontroversial untuk menemukan teori baru dan pemahaman baru yang lebih mendekati kebenaran. Secara garis besar pengertian konsep pluralisme agama itu tidak semata menunjuk pada kenyataan tentang adanya kemajemukan, namun perlu adanya keterlibatan aktif dan interaksi positif terhadap kenyataan majemuk itu. Dengan kata lain tiap pemeluk agama dituntut bukan saja mengakui keberadaan dan hak agama lain, tapi terlibat dalam usaha memahami perbedaan dan persamaan guna tercapainya kerukunan. Dan juga konsep pluralisme itu tidak dapat disamakan dengan relativisme yang menyebut "semua agama sama", dan juga pluralisme bukanlah sinkretisme, yakni menciptakan suatu agama baru dengan memadukan unsur-unsur tertentu dari beberapa agama. Yang perlu digaris-bawahi, penerapan konsep pluralisme agama harus dengan syarat yaitu, komitmen yang kokoh terhadap agama-agama masing. Seorang pluralis dalam berinteraksi dengan aneka ragam agama, tidak saja dituntut untuk membuka diri, belajar dan menghormati mitra dialognya. Tapi yang terpenting ia harus committed terhadap agama yang dianutnya. ${ }^{2}$

${ }^{1}$ Assefa Tolera, "Interrogating Religious Plurality and Separation of State and Religion in Ethiopia," Eastern Africa Social Science Research Review; Addis Ababa 33, no. 1 (January 2017): 39-72, https://search.proquest.com/docview/2298755332/abstract/6C41BFE71A304C2APQ/8.; Samuel Sami Everett, "Interfaith Dialogue and Faith-Based Social Activism in a State of Emergency: Laïcité and the Crisis of Religion in France," International Journal of Politics, Culture, and Society; New York 31, no. 4 (December 2018): 437-54, http://dx.doi.org/10.1007/s10767-018-9291-0.

${ }^{2}$ Alwi Shihab, Islam Inklusif: Menuju Sikap Terbuka Dalam Beragama (Bandung: Diterbitkan atas kerja sama AN Teve [dan] Penerbit Mizan, 1999), 42. 
Dewasa ini, sikap pluralis semakin diperhatikan dan diterima banyak pemikir dan tokoh keagamaan, meskipun dalam pengertian yang berbeda-beda. Benih-benih dan unsur-unsur pluralis juga ditemukan secara terpencar-pencar dalam berbagai pemikiran dan sikap yang mengedepankan toleransi dan keterbukaan. Di kalangan Muslim era modern, Seyyed Hossein Nasr, Frithjof Schuon (Muhammad Isa Nuruddin), Muhammad Legenhausen, Farid Essack, dan Abdul Aziz Sachedina adalah sebagian dari mereka yang membuka jalan menuju pluralisme agama. Di kalangan Kristiani ada William Cantwell Smith, W. Montgomery Watt, Huston Smith, Harvey Cox, John Hick, Hans Kung, dan Diana Eck telah membuka jalan bagi pluralisme agama. Di Indonesia, seperti A. Mukti Ali, Alwi Shihab, dan Nurcholish Madjid dari kalangan cendekiawan Muslim, Romo Franz Magnis Suseno dari cendekiawan Kristiani, adalah sedikit dari sekian banyak cendekiawan dan tokoh agama yang telah membuka jalan keterbukaan menuju pluralisme. ${ }^{3}$

Menurut Nurcholish Madjid, paham pluralisme bukan hanya sebatas ajaran kebenaran. Paham pluralisme tidak cukup hanya dengan sikap mengakui dan menerima kenyataan masyarakat yang majemuk, tapi harus disertai dengan sikap yang tulus untuk menerima kenyataan itu sebagai sebuah nilai positif. Pluralisme tidak boleh dipahami sekedar kebaikan negatif (negative good), yang dilihat dari kegunaannya untuk menyingkirkan fanatisme (to keep fanaticism at bay), yang hanya mengesankan fragmentasi, bukan pluralisme. Tetapi pluralisme harus dipahami sebagai pertalian sejati kebhinekaan dalam ikatan-ikatan keadaban (genuine engagement of diversities within the bonds of civility), dan bahkan pluralisme adalah masalah prinsip ajaran agama, dan keharusan bagi keselamatan umat manusia, bukan sebagai masalah prosedur atau tatacara pergaulan semata. ${ }^{4}$

Salah satu hal yang menarik telah dilakukan Nurcholish Madjid dalam pemikirannya adalah, dibuatnya penekanan distingsi antara "esoterisme" (al-bawathin) di satu segi dan "eksoterisme" (al-dzawabir) di segi lain. Adanya berbagai eksoterisme agama (organized religion) yang bisa disebut sebagai ajaran syariah pada hakikatnya mengajarkan esoterisme yang sama, yakni monoteisme (tawhid) dan sikap pasrah (alislam) tadi. $^{5}$

Pendapat Nurcholish Madjid ini dapat dilacak pada pemikiran filsafat perennial. Frithjof Schuon, genius terbesar metafisika tradisional, memberikan sumbangan pemikiran yang sangat orisinil, terutama dalam memperkaya isi esoterisme itu sendiri. Bagi Schuon hidup ini ada tingkatan-tingkatannya. Dari segi metafisik, hanya pada Tuhanlah, yang berada pada tingkat tertinggi, terdapat titik temu berbagai agama, sedangkan di tingkat bawahnya semua agama-agama itu saling berbeda. Sehubungan dengan kenyataan metafisik ini, dari segi epistemologis dapat pula dikatakan, perbedaan antara agama yang satu dengan agama yang lain juga mengecil

${ }^{3}$ Robert W. Hefner, "Modern Muslims and the Challenge of Plurality," Society; New York 51, no. 2 (April 2014): 131-39, http://dx.doi.org/10.1007/s12115-014-9752-7.

${ }^{4}$ Nurcholish Madjid, "Asas-Asas Pluralisme dan Toleransi dalam Masyarakat Madani," in Problematika Islam di Indonesia, ed. Abudin Nata (Jakarta: PT. Grasindo, 2002), 4-5.

${ }^{5}$ Budhy Munawar-Rahman, Islam Pluralis (Jakarta: Paramadina, 2001), 62.

Khazanah, Vol. 17 (2), 2019 
dan bersatu di tingkat tertinggi, sedangkan di tingkat bawahnya berbagai agama itu terpecah-pecah.

Pendapat bahwa pesan yang disampaikan agama-agama adalah sama pada tingkat esoterik, juga muncul dari Abul Kalam Azad pemikir Islam India, yang terkenal dengan jargonnya "al-Din wabid wa al-syari'at mukbtalifat; no difference in Din difference only in Sharia; agama tetap satu dan syariab berbeda-beda". Menurut Azad, petunjuk Tuhan tetap sama, dalam keadaan apapun petunjuk-petunjuk tersebut disampaikan kepada manusia dengan cara yang sama. Pesan yang disampaikan hanyalah bahwa kita harus beriman kepada Tuhan Yang Maha Esa dan berbuat baik sesuai dengan tingkat iman kita. Inilah yang ditawarkan agama kepada umat manusia di sepanjang zaman dan dalam segala keadaan dan itulah yang dimaksud dengan Din. ${ }^{6}$

Jadi pada dasarnya, teologi kesatuan agama-agama hanya terjadi pada tingkat esoterisme dan dalam esoterisme itu mengalir apa yang disebut dengan spiritualitas agama-agama. Dengan melihat sisi esoterisme dari agama-agama atau suatu ajaran kerohanian (spirit), maka manusia akan dibawa kepada apa yang merupakan hakikat dari agama. Dengan lain perkataan bahwa apa yang dimaksud dengan kesatuan agamaagama hanya dapat terjadi pada wilayah yang esoterik atau yang transenden. Agamaagama itu mesti berbeda satu sama lain pada dimensi eksoterik atau pada bentuk, institusi, syariat, doktrin dan simbol-simbol. Agama-agama secara substansif dapat menyatu, meski berbeda bentuk secara formal.

Melalui pendekatan esoterisme ini, kesatuan agama-agama atau pluralisme sangat mungkin tercapai, karena semua agama-agama pada akhirnya bertemu pada Tuhan. Di dalam Islam aspek esoterisme ini dikenal diperbincangan para tokoh tasawuf atau sufi yang banyak memiliki konsep tentang paham kesatuan (al-wahdat) seperti Wabdat al-Wujud, Wabdat al-Syubud, Wabdat al-Ummah dan Wabdat al-Adyan. Paham-paham ini sering ditanggapi secara pro dan kontra dari dulu hingga sekarang, khususnya paham $W$ abdat al-Adyan. Secara sederhana paham $W$ abdatul Adyan ini dapat dirumuskan, bahwa pada hakikatnya agama-agama yang ada bertujuan sama dan mengabdi kepada Tuhan yang sama pula. Perbedaan yang ada hanya dalam bentuk luar. Agama apapun dapat dipahami setara, karena bersumber dari Yang Satu, karena itu tidak dibenarkan menghakimi agama lain, dan malahan menganjurkan agar seseorang patuh dan konsisten pada agamanya masing-masing. Jadi tidak mengarah pada upaya menyatukan agama-agama, namun lebih ke arah konsep keberagamaan yang terbuka dan pluralis.

\section{Metode}

Artikel ini merupakan hasil dari penelitian kepustakaan (library research) yang mengangkat persoalan khazanah sufi seputar pluralisme agama. Studi dalam tulisan ini dapat dianggap penting, secara teoritis disamping dapat memperkaya khazanah pemikiran Islam secara lebih spesifik di bidang tasawuf, juga dapat mengukuhkan basis teologis bagi paham kemajemukan agama, yang pada tingkat praksis dapat mendorong

\footnotetext{
${ }^{6}$ Abul Kalam Azad, The Tarjuman Al-Qur'an (Hyderabad: Syed Abd al-Latif's Trust for Qur'an \& Other Cultural Studies, 1982), 153-60. 
terjadinya hubungan yang lebih harmonis intra dan antar pemeluk agama yang berbedabeda. Lebih dari itu, kalau selama ini diskursus tentang pluralisme agama dianggap selalu merujuk kepada karya-karya sarjana agama Barat, mereka yang mendefinisikan pluralisme sebagai pandangan bahwa Yang Maha Esa memanifestasi pada yang banyak atau bahwa agama-agama partikular merupakan respons terhadap Yang Mahaesa, ternyata beberapa tokoh tasawuf atau sufi sesungguhnya telah lama, lebih dahulu mendiskusikan hal itu secara filosofis dan mendalam. Anggapan bahwa isu pluralisme agama di dunia Islam semata-mata datang atau dipengaruhi pemikiran Barat tidak memiliki alasan yang kuat, sebab landasan mengenai ide dasar tentang kesatuan agamaagama telah ditancapkan oleh Al-Hallaj pada abad ke-10, dan lalu diwarisi oleh Ikhwanal-Shafa. Kemudian diskursus tentang tema ini secara ekstensif kemudian dibicarakan oleh Ibn 'Arabi dan Rumi pada abad ke-13, yang kemudian diikuti oleh para pengikut mereka di banyak belahan dunia Islam hingga abad ke-19 dan $20{ }^{7}$

\section{Pluralisme Agama dalam Perspektif Sufi}

Dalam studi agama-agama isu tentang pluralisme agama yang ramai dibicarakan sesungguhnya memiliki makna yang sama, jika tidak disebut identik, dengan paham Wabdat al-Adyan dari para sufi, terutama yang dicetuskan pertama kali oleh sufi-martir al-Hallaj dan kemudian dikembangkan dan disistematisir oleh sufi besar Ibn 'Arabi' dan dilanjutkan oleh sufi-penyair Jalaluddin al-Rumi, ${ }^{10}$ dan para sufi sesudahnya. Bila pluralism agama dipahami bahwa agama-agama merupakan jalan-jalan yang berbeda, tetapi menuju tujuan Yang Satu dan Sama, atau dengan bahasa lain, semua agama merupakan manifestasi-manifestasi dari Realitas Yang dalam pemahaman Wabdat alAdyan dari para sufi.

Walaupun istilah $W$ abdat al-Adyan atau kesatuan agama-agama sejatinya tidak pernah diungkapkan langsung oleh para sufi yang sering dianggap menganut paham tersebut seperti al-Hallaj dan Ibn 'Arabi, namun ajaran atau pendapat mereka berisi paham-paham tentang kesatuan ketuhanan, kesatuan ontologis, kesatuan esensi, dan kesatuan tujuan dengan jalan dan bentuk yang beraneka ragam. ${ }^{11}$ Para sarjana Muslim yang menjelajahi ide tentang kesatuan agama-agama pada awal dan pertengahan abad ke-20 seperti Mustafa Hilmi, Ahmad Amin, 'Afifi dan 'Abd Qadir Mahmud, selalu merujuk kepada gagasan-gagasan sufistik al-Hallaj dan Ibn 'Arabi, tidak kepada tokohtokoh dan konsep Barat. Bahkan, sufi-sufi India dan Persia yang berpaham wabdatulwujud pada akhir abad ke-13 hingga abad ke-19 secara terang-terangan menjelaskan

${ }^{7}$ Media Zainul Bahri, Satu Tuhan Banyak Agama: Pandanagan Sufistik Ibn 'Arabi, Rumi dan Al-jili (Jakarta: Mizan Pustaka, 2011), 41.

${ }^{8}$ Fathimah Usman, Wabdat Al-Adyan: Dialog Pluralisme Agama (Yogyakarta: LKiS, 2002), 2-3.

${ }^{9}$ Kautsar Azhari Noer, Tasawnf Perenial: Kearifan Kritis Kaum Sufi (Jakarta: Serambi, 2002), 36-

40.

${ }^{10}$ M. Maulana Marsudi, "Tasawuf Jalaluddin Ar-Rumi Perspektif Annemarie Schimmel," AlHikmah 3, no. 1 (2017): 49-70.R.

${ }^{11}$ Muhammad Robith Fuadi, "Memahami Tasawuf Ibnu Arabi dan Ibnu al Farid: Konsep al Hubb Illahi, Wahdat al Wujud, Wahdah al Syuhud dan Wahdat al Adyan," ULUL ALBAB Jurnal Studi Islam 14, no. 2 (2013).

Khazanah, Vol. 17 (2), 2019 
paham yang berisi ide tentang kesatuan agama-agama sebagai buah dari paham wahdatul-wujud Ibn 'Arabi. Di Persia ada Mahmud Shabistari, dan di India ada Dara Shikoh, 'Abd Rahman Chisti dan Hazrat Inayat Khan yang menyebarkan paham kesatuan agama-agama. ${ }^{12}$

Menurut kajian Media Zainul Bahri, istilah Wabdat al-Adyan (kesatuan agamaagama) dicetuskan pertama kali oleh Muhammad Mustafa Hilmi, Guru Besar Falsafah dan Tasawuf di Universitas Kairo dalam karyanya Ibn al-Farid wa Hubb Ilabi (1942). Dengan merujuk kepada karya-karya kesarjanaan tentang Ibn 'Arabi mulai dari Nicholson hingga 'Affi, ia berkesimpulan bahwa paham al-Hallaj, Ibn 'Arabi dan Ibn al-Farid tentang agama-agama disebutnya sebagai paham Wabdat al-Adyan. ${ }^{13}$

Esensi dari paham ini adalah teologi cinta, sebagaimana diungkapkan oleh Ibn 'Arabi dalam Tarjuman al-Ashwaq, "Hatiku telah menerima berbagai bentuk.... Aku beragama dengan Agama Cinta". ${ }^{14}$ Dalam Draka'ir al-A'laq Syarb Tarjuman al-Asywaq, Ibn 'Arabi memberi penjelasan mengenai kalimat itu:

"Tidak ada agama yang lebih unggul dari agama yang dibangun di atas cinta dan kerinduan kepada Dia, yang kepada-Nyalah aku patuh. Dan, ini khusus agama para pengikut Muhammad. Karena Muhammad SAW-lah di antara semua para nabi yang mempunyai kedudukan yang dicintai dan mencintai secara sempurna. Bersama dengan itu, dia juga orang yang terpilih, kekasih, dan memiliki sifat-sifat kenabian yang lain." 15

Semua penganut agama, dengan nama yang berbeda-beda dan dengan cara peribadatan dan penyembahannya masing-masing, menurut Ibn 'Arabi pada hakikatnya hendak mengekspresikan kecintaan kepada Tuhan. Semua pemeluk agama bergerak menuju Tuhan yang satu dan sama itu. Mereka sama-sama mencintai, mendambakan cinta-Nya, mendekat dan ingin menyatu dalam dekapan-Nya. Karena Dialah Pencipta segala yang ada dan Dia mencinta semuanya. Kemudian Ibn 'Arabi bersenandung:

Jalan dan cara pendakian (manusia) beragam

Tetapi mereka berjalan kearah kebenaran

Yang Satu

Dan para pendaki jalan kebenaran itu

Mencari jalan sendiri-sendiri

Bahasa kita beragam tetapi Engkaulah

Satu-satunya Yang Mahaindah

Dan masing-masing kita

Menuju Sang Mahaindah Yang Satu itu. ${ }^{16}$ 2011), 155.

${ }^{12}$ Bahri, Satu Tuhan Banyak, Agama: Pandanagan Sufistik. Ibn 'Arabi, Rumi Dan Al-Jili, 39-40.

${ }^{13}$ Bahri, 39.

${ }^{14}$ Bahri, 43.

${ }^{15}$ K.H. Husein Muhammad, Mengaji Pluralisme Kepada Mahaguru Pencerahan (Bandung: Mizan, ${ }^{16}$ Muhammad, 153. 
Dengan paham agama cinta ini diharapkan kegarangan hidup yang ditandai konflik dan permusuhan, dapat dikurangi. Disinilah letak urgensi paham pluralitas agama dalam sufisme yang mempunyai potensi spiritual untuk mengendorkan absolutisme para agamawan. Ada titik terang hubungan konsep cinta sufistik dan pengembangan pluralisme agama. Cinta kepada sesama tidak pernah muncul tanpa didasari sikap untuk menghargai perbedaan yang terdapat pada manusia. Agaknya perkembangan kehidupan keagamaan dan keberagamaan makin menghajatkan peran sufisme, karena di dalamnya terletak esensi dan masa depan agama.

Bagi pemeluk agama yang menempuh sikap eksklusif cenderung menunjukkan sikap "keras" terhadap yang "lainnya". Sebaliknya bagi yang menempuh sikap inklusif bersikap lebih fleksibel, akomodatif dan kondusif, dengan tanpa mengorbankan nilainilai agamanya sendiri. Begitu pula sikap pluralis yang dapat berinteraksi dengan aneka ragam agama dengan membuka diri, belajar dan menghormati mitra dialognya. ${ }^{17}$

Sebagai paham pluralisme agama, paham kesatuan agama ini, atau Wabdat alAdyan, sering ditanggapi secara pro dan kontra dari dulu hingga sekarang. Bahkan membicarakannya kadang bukan tanpa resiko, sebab tidak menutup kemungkinan memunculkan tuduhan sebagai upaya sinkretisme agama, keyakinan yang plin-plan, tidak konsisten dengan keyakinan sendiri dan sebagainya. Beberapa sufi, seperti AlHallaj dan Ibn al-'Arabi, acapkali dituduh sesat karena mengajarkan doktrin kesatuan agama-agama. ${ }^{18}$

\section{Pandangan Sufi terhadap Wahdatul Adyan}

Berikut ini akan dicoba dipaparkan sikap para sufi tasawuf dalam perjumpaan agama-agama atau paham $W$ abdat al-Adyan itu dengan menunjukan fakta-fakta historis tentang pandangan dan sikap para sufi terhadap agama-agama lain, sehingga terungkap dengan jelas kontak-kontak dan dialog-dialog antara Islam, yang diwakili oleh tasawuf, dan agama-agama lain serta pengaruh dialog-dialog itu terhadap tasawuf yang dapat dikatakan sebagai sepadan dengan paham pluralisme agama.

Secara sederhana dapat dirumuskan bahwa paham Wabdat al-Adyan mengajarkan bahwa pada hakikatnya agama-agama bertujuan sama dan mengabdi kepada Tuhan yang sama pula. Perbedaan yang ada hanya dalam bentuk luar dan namanya saja. Jadi, agama apapun dapat dipahami setara karena sumbernya satu, yakni Tuhan. Wabdat al-Adyan menyalahkan orang yang menyalahkan agama orang lain, sekaligus ia mengajarkan agar seseorang patuh dan konsisten pada ajaran agama masing-masing. ${ }^{19}$ Menurut doktrin ini, semua agama-agama sejati mewakili beragam manifestasi Satu Wujud, prinsip-prinsip berbeda mereka tidak lain adalah 'bentukbentuk' makna (ma'anı) arketipel yang dikenakan dalam jubah keberagaman. ${ }^{20}$

\footnotetext{
${ }^{17}$ M. Zainal Abidin, "Islam dan Tradisi Lokal dalam Perspektif Multikulturalisme," Millab: Jurnal Studi Agama 8, no. 2 (2009): 297-309.

${ }^{18}$ Hamka, Tasauf, Perkembangan Dan Pemurniannya (Jakarta: Pustaka Panjimas, 1983), 124.

${ }^{19}$ Usman, Wahdat Al-Adyan: Dialog Pluralisme Agama, 10.

${ }^{20}$ Leonard Lewisohn, "Pandangan Umum: Islam Iran Dan Sufisme Persia," in Warisan Sufi: Warisan Sufisme Persia Abad Pertengahan (1150-1500), trans. Ade Alimah (Yogyakarta: Pustaka Sufi, 2003), 58.
}

Khazanah, Vol. 17 (2), 2019 
Oleh karena itu, konsep ini sama sekali tidak mengarahkan pada upaya menyatukan agama-agama atau sinkretisme agama, tapi yang mungkin paham ini dapat dimasukkan ke dalam konsep keberagamaan yang terbuka, yakni paham pluralisme agama.

Berdasarkan perkiraan Ahmad Amin konsep $W$ abdat al-Adyan ini berawal dari penjabaran formulasi kalimat la ilaha illallah, yang mempunyai implikasi sangat dalam bagi kehidupan umat Islam. Segala sesuatu dipandang sebagai wujud dari karya Tuhan dan fenomena kebesaran-Nya. Bagi seorang sufi, tidak ada apa-apa dan tidak mencintai apapun kecuali Dia. Para sufi memandang bahwa Allah telah menurunkan petunjuk kepada umat manusia, berupa wahyu yang disampaikan melalui para rasul dan nabiNya, sehingga muncul ajaran tasawuf yang memandang bahwa keaneka-ragaman agama di dunia hanya sekedar bentuk, sedang hakikatnya sama, karena semuanya mempunyai sumber yang sama dan bertujuan untuk menyembah Dzat yang sama pula, yakni Pencipta alam semesta. ${ }^{21}$

Tokoh pertama yang mencetuskan paham Wabdat al-Adyan ini adalah sufimartir yang terkenal bernama Abu Manshur al-Hallaj. Paham ini digali al-Hallaj dari konsep tauhid, dengan penjelasan bahwa Tuhan itu adalah sesuatu yang "unik", sehingga tidak bisa disifati apapun. Penyifatan terhadap-Nya hanya akan membatasiNya. Maka konsep Tuhan yang satu harus pula dipahami secara "unik". Karena Tuhan adalah kesatuan yang mutlak dari keseluruhan, maka penyembahan dengan konsep monoteisme atau politeisme, tak ada masalah. Pada dasarnya perbedaan keduanya hanya berkaitan dengan logika, antara yang satu dan yang banyak. Dari situ, jika ditelusuri akan dijumpai kepercayaan-kepercayaan yang apabila ditafsirkan akan mengarahkan kepada satu Tuhan. ${ }^{22}$

Yang menarik dari pandangan al-Hallaj di atas adalah bahwa tidak ada perbedaan antara monoteisme dan politeisme. Karena menurutnya kufur (ingkar Tuhan) dan iman itu hanya berbeda dari segi namanya, bukan dari segi hakikatnya, karena antara keduanya tidak ada perbedaan. Sebuah riwayat mengisahkan, suatu ketika alHallaj melihat seorang Muslim sedang bertengkar dengan orang Yahudi serta memakimakinya. Ketika itu dia memalingkan muka seraya berkata : "Semua agama adalah milik Allah. Setiap golongan menganut suatu agama tanpa adanya pilihan, bahkan dipilihkan bagi mereka. Karena itu barangsiapa menyalahkan apa yang dianut golongan itu sama dengan dia telah menghukumi golongan tersebut menganut agama atas upayanya sendiri". 23

Setelah berpendapat demikian iapun bersenandung dengan syairnya :

"Aku memikirkan agama-agama dengan sunggub-sungguh,

kemudian sampailab pada kesimpulan

bahwa ia mempunyai banyak sekali cabang.

Maka janganlah sekali-kali mengajak seseorang kepada suatu agama,

${ }^{21}$ Ahmad Amin, Dzubr al-Islam, Juz II (Kairo: Maktabah al-Nahdhah al-Mishriyyah, 1977), 65-

66.

22Usman, Wabdat al-Adyan: Dialog Pluralisme Agama, 3

${ }^{23} \mathrm{Abu}$ al-Wafa' al-Ghanimi al-Taftazani, Sufi Dari Zaman Ke Zaman, trans. Ahmad Rofi Utsmani (Bandung: Penerbit Pustaka, 1985), 130. 
Karena sesunggubnya itu akan menghalangi

Untuk sampai pada tujuan yang kokoh.

Tetapi ajaklah melihat asal sumber segala kemuliaan dan makna, maka dia akan memahaminya",24

Ajaran al-Hallaj tentang $W$ abdat al-Adyan ini memiliki kaitan langsung dengan teori Nur Mubammad, karena menurut al-Hallaj Nur Mubamad merupakan pusat kesatuan nubuwwat (petunjuk) dari semua nabi. ${ }^{25}$ Oleh karena itu, agama yang dibawa oleh para nabi pada prinsipnya sama. Apalagi dalam keyakinan al-Hallaj, semua nabi merupakan "emanasi wujud", sebagaimana terumuskan dalam teori bulul-Nya. Oleh karena itu, pada dasarnya agama-agama berasal dari dan akan kembali kepada pokok yang satu, karena memancar dari cahaya yang satu. Baginya, perbedaan yang ada dalam agama-agama hanya sekedar perbedaan dalam bentuk dan namanya, sedangkan hakikatnya sama, bertujuan sama, yakni mengabdi kepada Tuhan yang sama pula. Jadi, semua agama, apapun nama-nya berasal dari Tuhan yang sama dan bertujuan yang sama.

Telah disebut di atas, bahwa paham Wahdat al-Adyan al-Hallaj ini dilandaskan pada pandangannya tentang tauhid. Memang banyak orang yang akan sulit memahami jalan pikiran ini. Bagaimana mungkin dapat terjadi, tauhid yang menghendaki konsep keesaan Tuhan secara mutlak, oleh al-Hallaj dijadikan landasan paham Wabdat alAdyan-nya yang 'mempersilahkan' kehadiran konsep ketuhanan yang beraneka-ragam. Hal ini seperti yang sedikit dijelaskan di atas, karena bagi al-Hallaj, Tuhan itu Esa, Unik, Sendiri dan terbukti Satu. Baginya, Tuhan tidak bisa disifati apa pun. Penyipatan terhadap-Nya akan membatasi-Nya, maka karena itu konsep Tuhan yang esa harus dipahami unik pula, karena Tuhan adalah kesatuan yang mutlak dari keseluruhan. Hanya terkait dengan konsep yang satu dan yang banyak. Dari situ, jika ditelusuri akan dijumpai kepercayaan-kepercayaan yang apabila ditafsirkan akan mengarah kepada satu Tuhan jua.

Tokoh sufi lainnya yang juga mengajarkan paham Wabdat al-Adyan adalah Syeikhul Akbar Ibn 'Arabi. Paham Ibn 'Arabi ini juga berpangkal dari konsep Nur Muhammad, sebab menurutnya, sumber agama-agama itu satu, yaitu hakekat Muhamad. Sebagai konsekwensinya, semua agama adalah satu dan semuanya itu kepunyaan Allah. Dan seorang yang benar-benar arif adalah seorang yang menyembah Allah dengan setiap ibadah kehidupannya. Dengan kata lain dapat dinyatakan bahwa ibadah yang benar adalah hendaknya seorang hamba memandang semua apapun sebagai termasuk ruang-lingkup realitas Dzat yang Tunggal yaitu Allah, sebagaimana maksud syairnya:

Dulu tidak kusenangi temanku

Jika agamanya lain dari agamaku,

Kini kalbuku bisa menampung semua.

Ilalang perburuan kijang atau biara pendeta

Kuil pemuja berbala atau Ka'bah baji berdatangan

Laub Taurat atau mushab al-Qur'an

\footnotetext{
${ }^{24}$ Usman, Wahdat al-Adyan: Dialog Pluralisme Agama, 14.

${ }^{25}$ Hamka, Tasauf, Perkembangan dan Pemurniannya, 123.

Khazanah, Vol. 17 (2), 2019
} 
Kupeluk agama cinta, kemanapun yang kutuju

Kendaraanku, cinta, ialab agamaku dan imanku. ${ }^{26}$

Untuk lebih memperjelas paham $W$ abdat al-Adyan Ibn 'Arabi ini, akan lebih menarik bila dikaitkan dengan teorinya tentang "Tuhan kepercayaan" (Ilah al-mu'taqad), yang disebut pula "Tuhan dalam kepercayaan" ( al-Ilah fi al-I'tiqad), atau "Tuhan kepercayaan ( Al-Haqq al-I'tiqad), atau "Tuhan yang diciptakan dalam kepercayaan" (alHaqq al-makbluq fi al-I'tiqad).

"Tuhan kepercayaan" adalah Tuhan dalam konsep, pengetahuan, penangkapan, atau persepsi manusia. Tuhan seperti itu bukanlah Tuhan sebagaimana Dia sebenarnya, tetapi adalah Tuhan ciptaan manusia. Tuhan seperti itu adalah Tuhan yang "dimasukkan" atau "ditempatkan" oleh manusia dalam kepercayaannya. "Bentuk", "gambar", atau "wajah" Tuhan seperti itu ditentukan atau diwarnai oleh manusia yang mempunyai kepercayaan kepada-Nya. "Apa yang diketahui" diwarnai oleh "apa yang mengetahui". "Warna air adalah warna bejana yang ditempatinya", kata Ibn 'Arabi. Dan itulah sebabnya Tuhan berkata, "Aku adalah dalam sangkaan hamba$\mathrm{Ku}$ tentang- $\mathrm{Ku}^{27}$

Teori Ibn 'Arabi ini mengingatkan kita kepada kritik Xenophanes (kira-kira 570-480 SM) terhadap antropomorfisme Tuhan, atau tuhan-tuhan. Kritik tokoh dari Kolophon, Asia Kecil sebagai berikut :

Seandainya sapi, kuda dan singa mempunyai tangan dan pandai menggambar seperti manusia, tentu kuda akan menggambarkan tuhan-tuhan menyerupai kuda, sapi akan menggambarkan tuhantuhan menyerupai sapi, dan dengan demikian mereka akan mengenakan rupa yang sama kepada tuhan-tuhan seperti terdapat pada mereka sendiri. Orang Etiopia mempunyai tuhan-tuhan hitam dan berbidung pesek, sedangkan orang Trasia mengatakan babwa tuban-tuban mereka bermata biru dan berambut merah. ${ }^{28}$

Dengan konsep "Tuhan kepercayaan" adalah Tuhan ciptaan manusia di atas, nampaknya Ibn 'Arabi ingin menjelaskan bahwa semua orang atau kelompok harus menyadari bahwa sebenarnya Tuhan yang menampakkan diri-Nya dalam berbagai bentuk itu adalah satu dan sama, itu juga, tidak lain.

Di mata Ibn 'Arabi, orang yang menyalahkan atau mencela kepercayaankepercayaan lain tentang Tuhan adalah orang yang bodoh. Pasalnya, Tuhan dalam kepercayaannya sendiri, sebagaimana kepercayaan-kepercayaan yang disalahkannya itu, bukanlah Tuhan sebagaimana Dia sebenarnya. Tuhan sebagaimana Dia sebenarnya tidak dapat diketahui. Ini sama dengan "mengetahui Tuhan yang tidak dapat diketahui" (to know the Unknowable God). Orang seperti itu mengakui hanya Tuhan dalam bentuk kepercayaan atau kepercayaan kelompoknya sendiri dan mengingkari Tuhan dalam bentuk-bentuk berbagai kepercayaan lain. Padahal, Tuhan yang menampakkan diriNya dalam semua bentuk kepercayaan yang berbeda-beda itu adalah satu dan sama.

\footnotetext{
${ }^{26}$ al-Taftazani, Sufi Dari Zaman Ke Zaman, 204-5.; bandingkan juga dengan Hamka, Tasauf, Perkembangan dan Pemurniannya, 156-157.

${ }^{27}$ Noer, Tasawnf Perenial: Kearifan Kritis Kaum Sufi, 36.

${ }^{28}$ K. Bertens, Sejarah Filsafat Yunani (Yogyakarta: Kanisius, 1989), 40.
} 
Kritik Ibn 'Arabi ini berlaku tidak hanya kepada setiap orang yang mencela kepercayaan-kepercayaan lain yang berbeda agama tetapi juga dalam lingkungan orangorang yang seagama. ${ }^{29}$

Lebih lanjut Ibn 'Arabi mengingatkan:

Maka berhati-hatilah agar engkau tidak mengikatkan diri kepada ajaran tertentu dan mengingkari ajaran lain yang manapun. Sebab, dengan begitu engkau akan kehilangan pengetahuan kebaikan yang banyak; sebenarnya engkau akan kehilangan pengetahuan yang benar tentang apa itu yang sebenarnya. Karena itu, terimalah sepenunya semua bentuk kepercayaan, karena Allah Ta'ala terlalu luas dan terlalu besar untuk dibatasi dalam satu ajaran tanpa ajaran lain. Dia berkata, "Kemana pun kamu berpaling di situ ada wajah Allah", tanpa menyebutkan arah tertentu manapun. ${ }^{30}$

Nampaknya pengetahuan yang benar tentang Tuhan, menurut Syekh al-Akbar ini, adalah pengetahuan yang tidak terikat oleh bentuk kepercayaan atau agama tertentu. Inilah pengetahuan para sufi, yang tidak pernah menolak Tuhan dalam kepercayaan, sekte, aliran, atau agama apapun. Ini berarti bahwa Tuhan, bagi mereka, adalah satu dan sama. Lalu dengan demikian timbul pertanyaan apakah kebenaran setiap agama itu sama?

Pandangan Ibn 'Arabi tentang persoalan kebenaran agama harus dijelaskan melalui ajarannya tentang perintah Tuhan. Ibn 'Arabi membagi perintah Tuhan kepada dua macam: "Perintah Penciptaan" (al-Amr al-Takwini, the Creative Command) yang disebut Kehendak Ilahi (al-Masyi'ah al-Ilabiyyah, the Divine Will) dan "Perintah Kewajiban" (al-Amr al-Taklifi, the Obligating Command) yang disebut Keinginan Ilahi (alIradah al-Ilabiyyah, the Divine Wish). Perintah penciptaan menyebabkan semua makhluk ada. Tidak sesuatu pun yang tidak memeatuhi perintah ini. Sedangkan perintah kewajiban disampaikan oleh Tuhan kepada para Nabi dalam bentuk wahyu yang harus mereka sampaikan kepada umat manusia. Perintah ini memberi kewajiban untuk mengabdi kepada Tuhan melalui salat, puasa, zakat, haji dan lain-lain. Perintah pertama pasti terpenuhi, sedangkan perintah kedua dapat terpenuhi dan dapat tidak terpenuhi. ${ }^{31}$

Karena itu dilihat dari segi perintah penciptaan, semua agama, baik agamaagama para penyembah Tuhan maupun agama-agama para penyembah berhala adalah sama dan benar. Artinya, semua agama itu sesuai dengan perintah penciptaan atau kehendak Ilahi. Dengan kata lain, semua agama, baik sesuai maupun yang tidak sesuai dengan perintah kewajiban, adalah sama karena semuanya memenuhi atau tidak bertentangan dengan perintah penciptaan. Dapat pula dikatakan bahwa semua agama adalah benar karena semuanya adalah penampakan diri atau teofani Tuhan, dalam pengertian ini, semua agama berasal dari Tuhan.

Akan tetapi, dilihat dari segi perintah kewajiban, semua agama tidak sama. Agama yang benar adalah agama yang sesuai dengan perintah kewajiban, yaitu agama yang sesuai dengan wahyu Tuhan yang disampaikan kepada para nabi. Agama inilah

${ }^{29}$ Noer, Tasawnf Perenial: Kearifan Kritis Kaum Sufi, 39-40.

${ }^{30}$ Musthafa ibn Sulaiman Bali Zadah al-Hanafi, Syarb Fushush Al-Hikam (Beirut: Dar al-Kutub al-'Ilmiyah, 2002), 149-50.

${ }^{31}$ Hanafi, 231-32.; Noer, Tasawnf Perenial: Kearifan Kritis Kaum Sufi, 41.

Khazanah, Vol. 17 (2), 2019 
yang menjamin keselamatan dan kebahagian, itulah menurutnya syariat yang dibawa oleh Nabi Muhammad SAW. Agama yang tidak benar adalah agama yang menyalahi perintah kewajiban, yaitu agama yang tidak sesuai dengan wahyu Tuhan, agama ini tidak menjamin keselamatan dan kebahagiaan.

Ibn 'Arabi menyatakan bahwa semua agama wahyu adalah cahaya. Di antara agama-agama ini, agama yang dibawa Muhammad ibarat cahaya matahari di tengah bintang gemintang. Ketika matahari muncul, cahaya bintang gemintang hilang dan terserap dalam cahaya matahari. Ketersembunyian mereka laksana pencabutan agamaagama wahyu lainnya yang terjadi melalui agama wahyu Muhammad. Meski demikian, agama-agama itu sebenarnya ada, sebagaimana eksistensi cahaya bintang diwujudkan. Ini menjelaskan mengapa kita telah disyaratkan dalam agama yang serba terbuka untuk memiliki keimanan terhadap kebenaran para rasul dan semua agama wahyu. Agamaagama itu tidak sia-sia (batil) dengan pencabutan yang merupakan pendapat orang yang bodoh. ${ }^{32}$

Seorang penyair sufi terbesar Persia, Jalaluddin al-Rumi (604-667H / 207-1273 M) yang juga penganut paham Wahdat al-Wujud, meneruskan tradisi pemikiran $W$ abdat al-Adyan. Ia melihat bahwa perselisihan paham antar umat beragama terjadi, karena mereka melihat agamanya masing-masing secara sendiri-sendiri. Mereka tidak melihat adanya kesatuan yang hakiki pada setiap agama, --sebagai hasil dari suatu perenungan yang seksama dan menyeluruh,-- karena mereka demikian terbelenggu oleh pikiranpikiran yang formal dan tradisional. Rumi selanjutnya mengatakan:

Perbedaan wujud makbluk-makbluk muncul karena bentuk zabirnya,

Apabila dapat menembus ke dalam makna yang hakiki kita akan tenteram;

O tulang belulang keberadaan! Disebabkan sudut pandang yang diperdekatkan

Maka kau sengit membeda-bedakan antara orang Islam, Kristen dan Majusi. ${ }^{33}$

Lebih jauh Rumi melukiskan pandangannya dalam sajak naratifnya tentang Gajah di Rumab Gelap yang melukiskan betapa sulit mengenal hakikat agama, hanya dari segi formal dan satu sudut pandang saja:

Adalah seekor gajah di rumah yang gelap,

Beberapa orang Hindu membawanya

Untuk dipertunjukean

Karena melihat dengan mata tidak mungkin,

Setiap orang merabanya dengan tangan.

Tangan yang seorang menyentub belalainya,

Ia berkata, "Makhluk ini seperti pipa air".

Yang lain meraba telinganya: $338-39$.

${ }^{32}$ Muhyiddin Ibn 'Arabi, Al-Futūhūāt Al-Makkkiyyah (Beirut: Dārul Kutub Al-'Ilmiyyah, 2011),

${ }^{33}$ Abdul Hadi W.M., "Kebhinekaan Beragama Dalam Perspektif Tasawuf," Jurnal Multikutural \& Multireligius HARMONI III, no. 9 (March 2004): 68. 
baginy a gajah tampak seperti kipas.

Yang lain memegang kakinya, ia berkata:

"Aku dapati bentuk gajah itu seperti sebuah tiang"

Yang lain meletakkan tangannya di punggungnya, ia berkata:

"Sesungguhnya gajah ini menyerupai singgasana".

Setelah masing-masing memasang lilin di tangannya,

Perbedaan pun akan lenyap dari kata-kata mereka. ${ }^{34}$

Lebih gamblang lagi, Rumi mengutarakan pandangannya tentang $W$ abdat alAdyan (kesatuan agama) dalam tulisannya Fibi Ma Fibi, sebagaimana yang dikutip Seyyed Hosein Nasr, di antaranya:

Walaupun jalan yang ditempuh bermacam-macam, namun tujuan banya satu.

Tidaklah kalian lihat babwa banyak. jalan menuju Ka'bah?

Beberapa melalui jalan Rum, beberapa lagi dari Syria, beberapa dari Persia, beberapa dari Cina, Beberapa lagi melalui lautan dari India dan Yaman. Sehingga jika kau tunjukan

Jalan itu bermacam-macam, dan perbedaannya tak, terbingga banyaknya, namun bila mana kalian sebutkan tujuanny a mereka semua akan sependapat bahwa banya satu. Hati semua orang terpusat menjadi satu pada Ka'bah. Hati terikat, nanar dan begitu cinta pada Ka'bah, tak memiliki ruang bagi perselisiban. ${ }^{35}$

Dalam syair lain, Rumi mengemukakan secara alegoris bahwa pertentangan dan perbedaan di antara agama-agama hanya persoalan kulit luar dan penamaan saja. Bila dipahami hakikat terdalamnya, perselisihan itu akan berakhir, seperti kisahnya tentang empat orang pelancong, masing-masing dari Persia, Turki, Arab dan Yunani. Mereka bertengkar tentang sesuatu yang akan mereka beli dengan sekeping uang mereka. "Saya ingin membeli angur" kata orang Persia. "Saya ingin membeli u₹um" kata orang Turki. "Saya ingin membeli 'inab, kata orang Arab. "Tidak, saya ingin membeli stafil, kata orang Yunani. Dalam anggapan mereka, keinginan masing-masing berbeda. Ketika datang pelancong lain yang ahli bahasa, dia menawarkan dapat membelikan semua harapan mereka dengan sekeping uang itu. Ternyata apa yang mereka inginkan adalah sama, yakni buah anggur (grapes) yang oleh si Persia disebut angur, oleh si Turki, u₹um, oleh si Arab 'inab dan oleh si Yunani stafil. ${ }^{36}$

Demikian gambaran orang-orang biasa yang mempertentangkan agama-agama, tetapi para sufi membantu menghentikan pertengkaran antara orang-orang yang berbeda agama sehingga tidak bertengkar lagi dan bisa menikmati "buah-buah anggur", yaitu agama-agama itu sendiri. Yang ingin dikatakan Rumi ialah formal ajaran ketuhanan dari agama-agama itu terbatas dibanding dengan makna yang sungguhnya

\footnotetext{
${ }^{34}$ R. Mulyadhi Kartanegara, Renungan Mistik Jalal-Ad-Din Rumi (Jakarta: Pustaka Jaya, 1986), 92.

${ }^{35}$ Sayyid Hosein Nasr, Tasauf Dulu Dan Sekarang, trans. Abdul Hadi W.M. (Jakarta: Pustaka Firdaus, 2002), 215.

${ }^{36}$ Noer, Tasawnf Perenial: Kearifan Kritis Kaum Sufi, 54-55. Kartanegara, Renungan Mistik Jalal-AdDin Rumi, 94-95.
} 
terkandung dalam bentuk formal yang mewadahinya. Dengan melihat perwujudan keyakinan kepada Yang satu dalam wadah yang berbeda-beda, agama benar-benar sebagaitangga naik menuju Yang Transenden. Karena itu Rumi dalam salah satu syair bersenandung :

"...aku adalah seorang Muslim,

tetapi aku juga seorang Nasrani, Brabmaisme,

dan Zarathustraisme.

Aku pasrah kepada-Mu al-Haqq Yang Mahamulia,

... aku banya mempunyai satu tempat ibadah,

masjid atan gereja atan berbala,

Tujuanku banya kepada Dzat Yang Mahamulia. ${ }^{37}$

Walaupun begitu bersemangatnya Rumi menyampaikan ide-ide Wabdat alAdyan, mungkin seperti juga sufi yang lainnya, dia mengakui bahwa tidak mudah baginya untuk menyingkapkan rahasia-rahasia itu kepada orang-orang awam supaya mereka dapat memahaminya, sehingga dengan nada pesimis Rumi bertanya:

Jika 'ku harus bersibuk diri dengan, menjelaskan hal-halyang rumit ini, sehingga seorang suci yang telab mencapai Tuban pun akan kehilangan urutan ceramah ini. Maka bagaimana mungkin untuk menyingkapkan rahasia-rabasia dan keadaan-keadaan (abwal) mistis yang demikian itu kepada orang-orang awam ?... Seseorang yang tidak dapat melihat seekor unta di puncak, sebuah menara, bagaimana dia kemudian dapat melihat seutas rambut di mulut sang unta ${ }^{38}$.

Ungkapan-ungkapan para sufi di atas, atau lainnya, sepintas dapat menggiring kepada kesimpulan keliru bahwa mereka menganggap perbedaan antara Islam dan kepercayaan-kepercayaan lainnya tidak signifikan, sebagaimana paham pluralisme yang liberal atau reduktif. Padahal pada kenyataannya yang ingin disampaikan adalah pesan kecaman terhadap sikap keberagaman, berupa kemunafikan, yaitu tanda lahiriahnya sama dengan Islam, tapi tanpa keimanan batiniah yang otentik. Seakan mereka berkata, akan lebih baik memiliki kesamaaan dengan keyakinan yang salah namun dengan tulus, ketimbang menjadi munafik, secara lahiriah mengaku muslim, namun secara batiniah ia menyembah thagut. Para sufi itu ingin menekan kemunafikan sebagai lawan keimanan yang tulus. Karena bagi mereka kemunafikan lebih buruk dari seorang seperti zoroaster atau penyembah berhala yang tulus. Yang menjadi problem adalah mereka lebih suka menyampaikannya dalam ungkapan puitis atas keimanan dan penolakan terhadap kemunafikan itu melalui lambang-lambang agama lain atau bahkan penyembahan berhala.

Paham Wabdatul al-Adyan yang berisi pemikiran-pemikiran inklusif-pluralistik dari para sufi itu kemudian ternyata menjadi doktrin rintisan bagi corak sufisme Persia abad pertengahan yang secara perlahan menjadi sebuah kekuatan budaya terkemuka di dunia Islam. Watak utamanya adalah toleransi dan anti-sektarianisme. Para sejarawan seperti Hodgson menjelaskan bahwa pada umumnya para sufi Persia itu cenderung toleran terhadap perbedaan-perbedaan. Bagi kebanyakan mereka, terutama pada

\footnotetext{
${ }^{37}$ Amin, Drubr al-Islam, 66.

${ }^{38}$ Kartanegara, Renungan Mistik Jalal-Ad-Din Rumi, 95.
} 
periode pertengahan awal, bahkan perbedaan antara Islam dan tradisi-tradisi kultural lain seperti Kristen bersifat sekunder. Yang penting bagi mereka adalah kecenderungan rohani kalbu kepada Tuhan. ${ }^{39}$

Usaha-usaha para sufi dalam mengembangkan sikap keberagamaan yang inklusif-pluralistik terus berkembang ke arah yang lebih praktis. Dalam risalah IndoPersia, Mir'at al-Haqa'iq karya Abd ar-Rahman Chisti (w. 1683), hal tersebut nampak terlihat. Dalam karyanya ini, Chisti secara spesifik menyebutkan dalam pendahuluannya bahwa alasannya menyusun Mir'at al-Haqa'iq adalah untuk menafsirkan Bhagavadgita versi sufi. Atau lebih jelasnya Mir'at al-Haqåiq adalah merupakan interpretasi eklektik terhadap teks Sansekerta itu yang dikemas dengan "catatan-catatan Islami" yang diseleksi oleh Chisti dari referensi al-Qur'an, Hadis dan kutipan-kutipan syair Persia. ${ }^{40}$

Dalam karyanya itu, Chisti bersimpulan bahwa Bhagavadgita adalah sebuah buku di mana Krishna menjelaskan kepada Arjuna rahasia tauhid secara analogis. Secara esensial Chisti memandang Krishna bukan sebagai Tuhan maupun dewa, tetapi lebih sebagai muwabhid sejati, seorang yang memahami rahasia-rahasia Wabdat al-Wujud, dan bahkan mungkin seorang Nabi. ${ }^{41}$

Penafsiran Chisti tersebut dalam konteks hubungan antar agama di India ketika itu memiliki dua sisi. Efek paling penting adalah hal ini memberikan otoritas kepada Bhagavadgita masuk dalam jenis kitab samawi, dan menyebabkan ada kebolehan menerjemahkan dan mengkajinya bagi orang-orang Islam. Efek yang kedua dari kajian ini adalah bersifat politis karena memasukkan masyarakat kerajan Mughal yang mayoritas Hindu ke dalam kelompok 'orang-orang yang diberi al-Kitab (Abl al-Kitab). ${ }^{42}$

Sufi India lainnya, adalah Hazrat Inayat Khan yang terdidik dengan tarekat Chistiyyah, Naqsyabandiyah, Qadiriyah dan Suhrawardiyah, adalah seorang tokoh dialog spiritual yang sangat berani. Ia sama sekali tidak ragu melakukan pengembaraan spiritual ke dalam jantung agama-agama lain. Ini dilakukannya karena ia percaya bahwa semua agama secara esensial adalah satu karena hanya ada satu Tuhan dan satu kebenaran.

Ia menegaskan bahwa agama-agama memang banyak dan berbeda satu sama lain, tetapi hanya dalam bentuk, seperti nada-nada dalam sebuah musik. Semua adalah nada-nada yang berbeda adalah benar; dan ketika bertemu jadilah musik. Sama dengan agama: kebenaran esensial adalah satu, tetapi aspek-aspeknya berbeda. Orang-orang yang berkelahi karena bentu-bentuk luar akan selalu terus menerus berkelahi, tetapi orang-orang yang mengakui kebenaran batini tidak akan berselisih dan dengan demikian akan mampu mengharmoniskan orang-orang semua agama. ${ }^{43}$

\footnotetext{
${ }^{39}$ Leonard Lewisohn, "Pandangan Umum: Islam Iran Dan Sufisme Persia," 55.

${ }^{40}$ Roderic Vassie, "Abd Ar-Rahman Chisti Dan Bhagavadgita: Teori Kesatuan Agama Dalam Praktek," in Warisan Sufi: Warisan Sufisme Persia Abad Pertengahan (1150-1500) (Yogyakarta: Pustaka Sufi, 2003), 645-46.

${ }^{41}$ Roderic Vassie, 647.

${ }^{42}$ Roderic Vassie, 647.

${ }^{43}$ Hazrat Inayat Khan, Kesatuan Ideal Agama-Agama, trans. Yulian Aris Fauzi (Yogyakarta: Putra Langit, 2003), 16-17.
}

Khazanah, Vol. 17 (2), 2019 
Inayat Khan sangat menekankan kesatuan, yang adalah syarat mutlak untuk mencapai kehidupan yang benar. Menurutnya, kitab-kitab suci yang dimiliki orangorang beragama dilihat secara eksternal tampak berbeda-beda, namun jika dilihat benang merah yang menghubungkan semua agama, maka semuanya mempunyai pesan kesatuan sebagai kebenaran sentral, tetapi manusia begitu tertarik dan terpikat kepada puisi-puisi kitab suci itu sehingga lupa kepada suara batini kitab-kitab suci itu ${ }^{44}$.

Salah seorang sufi kontemporer lain, yang mempunyai perhatian serius pada gagasan dan upaya dialog agama-agama adalah Idries Shah. Ia memandang bahwa perbedaan agama tidak menjadi persoalan bagi tasawuf, karena esensi semua agama adalah sama: tasawuf itu sendiri. Idris Shah membenarkan upaya pencarian "titik temu" antar agama, karena itu ia aktif terlibat dalam dialog agama-agama. Melalui kuliah yang diberikannya ia berupaya menjawab pertanyaan tentang kemungkinan kerjasama agama-agama dalam menghadapi masalah bersama umat manusia. Melalui paper kuliahnya yang berjudul The Elephant in the Dark ${ }^{45}$, ia menawarkan pendekatan sufi sebagai landasan dialog antar agama untuk menghilangkan perangkap pandangan sempit yang merendahkan agama lain yang disebabkan oleh ambisi politis, kecenderungan ekspansi ekonomi, dan pertarungan ideologis.

Berdasarkan pada bukti-bukti historis dari pendapat para sufi yang dipaparkan di atas, dengan jujur harus diakui bahwa kaum muslim yang diwakili oleh para sufi tersebut, merupakan kelompok yang paling toleran, paling simpatik, paling terbuka, dan paling ramah terhadap agama-agama lain. Sikap tersebut didorong oleh keyakinan mereka yang cukup luas dan dalam terhadap ajaran Islam. Sikap ini tidak merusak iman mereka dan tidak dapat dilihat sebagai ketidak-konsistenan dan kegoyahan iman mereka. Justru sebaliknya menunjukkan kekokohan sejati iman mereka dan kepercayaan diri yang dalam dengan berani memasuki jantung agama-agama lain. Kekokohan sejati iman tersebut tidak memerlukan "benteng" ketertutupan, "benteng" eksklusivisme, "benteng" isolasi, tapi "benteng" mereka yang paling kokoh adalah iman mereka kepada Tuhan itu sendiri.

Bagi para sufi tersebut, perjumpaan Islam dan agama-agama lain, bukan sekedar untuk memahami agama-agama lain itu, tetapi lebih jauh untuk memperkaya, menyuburkan, dan memperdalam pengalaman keagamaan dan spritual mereka. Mereka sangat terbuka kepada siapapun dan siap menyerap tradisi-tradisi dan sumber-sumber hikmah lain,--seperti pada sikap dan pemikiran Suhrawardi al-Maqtul ${ }^{46}-$, , tanpa mengingkari iman mereka, tanpa kehilangan identitas asli, tanpa jatuh ke dalam sikretisme, apalagi melakukan konversi kepada agama lain.

\footnotetext{
${ }^{44}$ Khan, 313-14.

${ }^{45}$ Idries Shah, Meraba Gajah Dalam Gelap: Sebuah Upaya Dialog Islam-Kristen, trans. Tim Grafiti Press (Jakarta: PT. Pustaka Grafiti Pres, 1986).

${ }^{46}$ Menurut S. H. Nasr, sumber-sumber yang menjadi sandaran pemikiran Suhrawardi sangat banyak dan beragam, disamping dari pemikir Islam seperti Ibn Sina, al-Hallaj dan Al-Ghazali, ia juga menyerap dari aliran Pythagoras, Platonisme dan Hermesisme dari Yunani dan Mediterian, juga sumbersumber hikmah Persia Kuno dan Zoroaster. Seyyed Hossein Nasr, Three Muslim Sages (Cambridge: Harvard University Press, 1964). 
Karena itu pandangan $W$ abdat al-Adyan para sufi tentang kesatuan agamaagama atau lebih tepatnya "kesatuan transenden agama-agama", bukanlah pandangan yang serampangan dan gegabah tanpa dasar. Pandangan ini didukung oleh dasar yang kuat dalam sistem pemikiran mereka, tidak seperti dicerminkan oleh tuduhan bahwa mereka menyamakan begitu saja semua agama.

Dalam memandang agama yang berbeda-beda dan beraneka-ragam, para sufi menggunakan perspektif metafisika yang menggambarkan kaitan Yang Satu dengan "yang berbagai" seperti hubungan matahari dengan pancaran sinarnya yang tidak terkira banyak. Secara hakiki sinar yang banyak dan berpencar itu menuju kepada Yang Satu, karena berasal dari Yang Satu, dengan demikian memiliki kesatuan batin yang tersembunyi, walaupun penampakannya beraneka-ragam. Para sufi ketika memandang agama-agama yang berbeda, mereka mentransendensikan bentuyk dan menembus jauh ke dalam makna terdalam ajaran setiap agama, yang pada dasarnya bersifat universal itu.

\section{Simpulan}

Dalam rangka menghadapi problem kemanusiaan universal sekarang ini, lewat kemampuannya menggali makna batini (the inner meaning) dengan menerobos bentukbentuk lahiriah, tasawuf, nampaknya dapat menjadi wakil Islam yang paling kompeten untuk melakukan dialog-dialog sejati dengan agama-agama lain. Tasawuf inilah mungkin satu-satunya aspek Islam yang bisa menjawab persoalan-persoalan dialog agama-agama dengan seadil-adilnya, tanpa mengebiri kodrat agama sendiri. Tasawuf bisa memenuhi kebutuhan dialog tersebut dengan kunci bikmah perennial dan universalnya, yang mampu membuka pintu-pintu penghalang dialog itu. Dan memang dalam sejarah Islam sendiri, adalah tasawuflah yang selalu berada di garda depan dalam dialog Islam dengan agama-agama dan kebudayaan lain.

Ajaran para sufi tentang $W$ abdat al-Adyan mengajarkan bahwa pada hakikatnya semua agama bertujuan sama dan mengabdi kepada Tuhan yang sama pula. Kesatuan pesan itu adalah esoterik, kesatuan esensi, kesatuan substansi, bukan kesatuan eksoterik, bukan kesatuan kulit atau bukan kesatuan bentuk. Kesatuan agama-agama bukan dalam doktrin, ajaran, bentuk, atau cara ibadah, tetapi dalam esensinya yaitu Tuhan itu sendiri.

Pandangan para sufi mengakui adanya penyelewengan-penyelewengan dalam agama-agama yang merupakan pengingkaran terhadap Tuhan. Dalam arti ini, semua agama tidaklah sama. Agama yang diselewengkan tidak akan membawa kepada keselamatan dan kebahagiaan. Agama yang diterima oleh Tuhan dan menjamin keselamatan dan kebahagiaan itu adalah agama yang mematuhi wahyu Tuhan, atau seperti yang dikatakan oleh Ibn 'Arabi, agama yang mematuhi Perintah Kewajiban (alAmr al-Taklifi).

Akhirnya dapat dipahami bahwa dalam doktrin Wabdatal-Adyan yang dikemukakan para sufi, ada sebuah cermin bening, bahwa sufisme atau dimensi esoterik dapat menjadi semacam "jembatan" atau "wadah" yang mempertemukan semua tradisi agama-agama. Pengalaman atau perjumpaan spiritual dengan Yang Mutlak, secara tidak direkayasa, ternyata sama-sama dialami oleh orang-orang suci pada 
tiap-tiap agama hingga melahirkan kesadaran dan keyakinan kuat bahwa secara esoterik semua wujud, bentuk atau penjelmaan yang berbeda-beda dari agama-agama, sejatinya berasal dari Sumber yang Sama.

Sudah lama kita bergelut dengan ajaran-ajaran keagamaan dengan pendekatan formalistik yang kaku, pengetahuan yang tunggal, yang dianggap sebagai kebenaran agama yang final. Keberagamaan seperti ini acap mengundang kesalaham-pahaman, intoleransi perseteruan, penyesatan, dan pengkafiran, lalu akhirnya melahirkan kekerasan atas nama agama. Hal ini tentu saja tidak menguntungkan bagi kehidupan bersama, baik sebagai umat, bangsa, negara, maupun warga dunia.

Saat ini pemeluk agama-agama tidak mungkin lagi hidup menyendiri secara ekslusif, tertutup, terpisah, tetapi mesti terlibat dialog dan perjumpaan dengan pemeluk agama yang lain. Sampai-sampai ada ungkapan to be religious, someone bas to be interreligious, namun kiranya masih nanyak umat beragama yang kaget dan tidak siap memasuki kehidupan dan pergaulan lintas umat beragama yang semakin mengglobal dan intens ini.

Dalam suasana kehidupan yang pluralistik sekarang ini, untuk mewujudkan sebuah sikap dan pengalaman keagamaan (religious experience) yang dapat menuntun manusia menuju kebaikan bersama, maka paham pluralisme agama non-reduktif seperti paham Wabdat al-Adyan ini perlu dielaborasi lebih dalam. Dan terbukti lewat kemampuannya menggali makna batini (the inner meaning) yang menerobos bentukbentuk lahiriah, sufisme menjadi wakil Islam yang paling kompeten untuk dialog dengan agama lain. Mungkin hanya sufisme, kalau bukan, adalah satu-satunya aspek Islam yang bisa menjawab persoalan dialog agama-agama, tanpa mengebiri kodrat agama sendiri. Dengan paham sufisme tentang kebenaran yang bersifat esensial, universal dan meta-historis, maka seruan al-Qur'an kepada kalimatun sawa', titik-temu (comman-platform) akan menjadi landasan etis bagi kehidupan beragama semua bangsa.

\section{Daftar Pustaka}

Abidin, M. Zainal. "Islam Dan Tradisi Lokal Dalam Perspektif Multikulturalisme." Millab: Jurnal Studi Agama 8, no. 2 (2009): 297-309.

'Arabi, Muhyiddin Ibn. Al-Futūhät Al-Makkiyyah. Beirut: Dārul Kutub Al-'Ilmiyyah, 2011.

Azad, Abul Kalam. The Tarjuman Al-Qur'an. Hyderabad: Syed Abd al-Latif's Trust for Qur'an \& Other Cultural Studies, 1982.

Bahri, Media Zainul. Satu Tuhan Banyak. Agama: Pandanagan Sufistik. Ibn 'Arabi, Rumi Dan Al-jili. Jakarta: Mizan Pustaka, 2011.

Bertens, K. Sejarah Filsafat Yunani. Yogyakarta: Kanisius, 1989.

Everett, Samuel Sami. "Interfaith Dialogue and Faith-Based Social Activism in a State of Emergency: Laïcité and the Crisis of Religion in France." International Journal 
of Politics, Culture, and Society; New York 31, no. 4 (December 2018): 437-54. http://dx.doi.org/10.1007/s10767-018-9291-0.

Fuadi, Muhammad Robith. "Memahami Tasawuf Ibnuu Arabi Dan Ibnuu al Farid: Konsep al Hubb Illahi, Wahdat al Wujud, Wahdah al Syuhud Dan Wahdat al Adyan." ULUL ALBAB Jurnal Studi Islam 14, no. 2 (2013).

Hamka. Tasauf, Perkembangan Dan Pemurniannya. Jakarta: Pustaka Panjimas, 1983.

Hanafi, Musthafa ibn Sulaiman Bali Zadah al-. Syarb Fushush Al-Hikam. Beirut: Dar alKutub al-'Ilmiyah, 2002.

Hefner, Robert W. "Modern Muslims and the Challenge of Plurality." Society; New York 51, no. 2 (April 2014): 131-39. http://dx.doi.org/10.1007/s12115-014-97527.

Kartanegara, R. Mulyadhi. Renungan Mistik Jalal-Ad-Din Rumi. Jakarta: Pustaka Jaya, 1986.

Khan, Hazrat Inayat. Kesatuan Ideal Agama-Agama. Translated by Yulian Aris Fauzi. Yogyakarta: Putra Langit, 2003.

Leonard Lewisohn. "Pandangan Umum: Islam Iran Dan Sufisme Persia." In Warisan Sufi: Warisan Sufisme Persia Abad Pertengahan (1150-1500), translated by Ade Alimah. Yogyakarta: Pustaka Sufi, 2003.

Madjid, Nurcholish. "Asas-Asas Pluralisme Dan Toleransi Dalam Masyarakat Madani." In Problematika Islam Di Indonesia, edited by Abudin Nata. Jakarta: PT. Grasindo, 2002.

Marsudi, M. Maulana. "Tasawuf Jalaluddin Ar-Rumi Perspektif Annemarie Schimmel." Al-Hikmah 3, no. 1 (2017): 49-70.

Muhammad, K.H. Husein. Mengaji Pluralisme Kepada Mahaguru Pencerahan. Bandung: Mizan, 2011.

Munawar-Rahman, Budhy. Islam Pluralis. Jakarta: Paramadina, 2001.

Nasr, Sayyid Hosein. Tasauf Dulu Dan Sekarang. Translated by Abdul Hadi W.M. Jakarta: Pustaka Firdaus, 2002.

Nasr, Seyyed Hossein. Three Muslim Sages. Cambridge: Harvard University Press, 1964.

Noer, Kautsar Azhari. Tasamuf Perenial: Kearifan Kritis Kaum Sufi. Jakarta: Serambi, 2002.

Roderic Vassie. "Abd Ar-Rahman Chisti Dan Bhagavadgita: Teori Kesatuan Agama Dalam Praktek." In Warisan Sufi: Warisan Sufisme Persia Abad Pertengahan (11501500). Yogyakarta: Pustaka Sufi, 2003.

Shah, Idries. Meraba Gajah Dalam Gelap: Sebuah Upaya Dialog Islam-Kristen. Translated by Tim Grafiti Press. Jakarta: PT. Pustaka Grafiti Pres, 1986. 
Ilham Masykuri Hamdi

Shihab, Alwi. Islam Inklusif: Menuju Sikap Terbuka Dalam Beragama. Bandung: Diterbitkan atas kerja sama AN Teve [dan] Penerbit Mizan, 1999.

Taftazani, Abu al-Wafa' al-Ghanimi al-. Sufi Dari Zaman Ke Zaman. Translated by Ahmad Rofi Utsmani. Bandung: Penerbit Pustaka, 1985.

Tolera, Assefa. "Interrogating Religious Plurality and Separation of State and Religion in Ethiopia." Eastern Africa Social Science Research Review; Addis Ababa 33, no. 1 January 2017): $39-72$. https://search.proquest.com/docview/2298755332/abstract/6C41BFE71A3 04C2APQ/8.

Usman, Fathimah. Wabdat Al-Adyan: Dialog Pluralisme Agama. Yogyakarta: LKiS, 2002.

W.M., Abdul Hadi. "Kebhinekaan Beragama Dalam Perspektif Tasawuf." Jurnal Multikutural \& Multireligius HARMONI III, no. 9 (March 2004). 